\title{
Pengaruh Harga, Citra Merek Dan Kualitas Terhadap Minat Beli Produk Private Label
}

\author{
Noverita Wirayanthy ${ }^{1}$, Singgih Santoso ${ }^{2 *}$ \\ Universitas Kristen Duta Wacana \\ *Korespondensi: singgih.santoso@gmail.com
}

\begin{abstract}
Abstrak
Penelitian ini bertujuan untuk mengetahui pengaruh dari: 1) persepsi harga, 2) citra merk dan 3) kualitas produk terhadap minat beli konsumen pada produk private label Indomaret di Yogyakarta. Penelitian ini berjenis kuantitatif. Populasi dari penelitian ini adalah konsumen Indomaret di Yogyakarta dan sampel yang diambil sebanyak 100 orang dengan teknik pengambilan sampel menggunakan metode purposive sampling. Teknik analisa data menggunakan Analisa regresi linear berganda, Uji - T dan Uji - F. Hasil penelitian menunjukkan bahwa terdapat pengaruh positif persepsi harga terhadap minat beli konsumen pada produk private label Indomaret di Yogyakarta, tidak adanya pengaruh positif citra merek terhadap minat beli konsumen pada produk private label Indomaret di Yogyakarta, terdapat pengaruh positif kualitas produk terhadap minat beli konsumen pada produk private label Indomaret di Yogyakarta, serta terdapat pengaruh positif persepsi harga, citra merek dan kualitas produk terhadap minat beli konsumen pada produk private label Indomaret di Yogyakarta.
\end{abstract}

Kata kunci: Persepsi Harga, Citra Merek, Kualitas Produk, Minat Beli,Produk Private Label

\section{Abstract}

This study aims to determine the effect of: 1) perceived prices, 2) brand image and 3) product quality towards consumer buying interest in Indomaret's private label products in Yogyakarta. This research is of quantitative type. The population of this study is Indomaret consumers in Yogyakarta and the samples taken were 100 people with the sampling technique using the purposive sampling method. Data analysis techniques used multiple linear regression analysis, T-Test and F-Test. The results showed that there was a positive influence on the perception of prices towards consumer buying interest in Indomaret's private label products in Yogyakarta, there was no positive effect of brand image on consumer buying interest in products Indomaret's private label in Yogyakarta, there is a positive influence on product quality on consumer buying interest in Indomaret's private label products in Yogyakarta, and there is a positive influence on price perception, brand image and product quality towards consumer buying interest in Indomaret's private label products in Yogyakarta.

Keywords: Price Perception, Brand Image, Product Quality, Buying Interest, Private Label Product

\section{A. PENDAHULUAN}

Saat ini telah banyak bermunculan ritel modern di Indonesia, termasuk di Daerah Istimewa Yogyakarta (DIY), seperti minimarket, supermarket, hypermarket, department store dan convinience store dengan berbagai nama dan secara tidak langsung telah menjadi salah satu faktor pendorong meningkatnya keinginan berbelanja seseorang. Salah satu ritel yang sering dijumpai adalah Indomaret.

Data dari Nielsen Ritel Audit sepanjang bulan Maret 2017 menunjukkan Indomaret berada di urutan tertinggi dengan jumlah gerai mencapai 14.200 gerai, disusul dengan Alfamart dengan 12.700 gerai. Dengan begitu tingkat persaingan antar ritel modern khususnya Indomaret dan Alfamart serta ritel yang lain pun semakin kuat dan hal ini menjadikan setiap ritel modern memiliki strategi untuk memenangkan persaingan tersebut. Salah satu strategi yang dapat dilakukan adalah membuat produk private label.

Produk private label merupakan merek yang dimiliki oleh pengecer atau grosir untuk lini produk atau variasi produk di bawah kontrol ritel tersebut dan didistribusikan khusus oleh ritel (Kotler 2006). Soliha (2008) menyatakan pentingnya peran ritel dalam mempertemukan konsumen dengan barang akhir yang akan dikonsumsi. Dengan berkembangnya teknologi dan perluasan distribusi, jumlah ritel modern dari tahun ke tahun telah menggeser peran ritel tradisional. 
Pada tahun 1999 proporsi ritel modern hanya 35\%, sedangkan pada tahun 2004 telah meningkat menjadi $47 \%$ dan diperkirakan terus melaju meninggalkan ritel tradisional (Soliha, 2008). Asosiasi Pengelola Pusat Belanja Indonesia (APPBI) memperkirakan pertumbuhan toko modern di Indonesia dalam kurun waktu 2012-2015 sekitar 5\% per tahun. Jika dirinci, pertumbuhan gerai minimarket adalah $15 \%$ per tahun, seiring dengan derasnya urbanisasi, peningkatan pendapatan penduduk dan perubahan gaya hidup perkotaan (Nur Aini et. al., 2016).

Salah satu produk yang saat ini banyak dijual di ritel modern adalah produk private label. ecara umum, private label adalah produk yang diproduksi dan dijual atas keinginan atas nama peritel itu sendiri (Bramasto dan Indriani, 2017). Banyaknya produk private label yang mulai muncul saat ini secara tidak langsung telah menambah variasi produk yang dapat di pilih konsumen. Pada dasarnya produk private label memiliki nilai fungsional yang hampir sama dengan produk merek lainnya, akan tetapi produk private label merupakan produk yang sering dianggap sebagai produk alternatif. Hal itu bisa dikarenakan konsumen lebih mengenal dan percaya pada produk lain yang telah mereka konsumsi selama sebelum adanya produk private label yang dikeluarkan oleh peritel. Indomaret merupakan salah satu ritel yang mempunyai produk private label. Cukup banyak produk private label Indomaret yang bisa dijumpai berbelanja ke Indomaret. Dalam setahun, Indomaret mengeluarkan 100-200 item produk private label dengan harga lebih murah dan penempatan barang yang menarik. Dengan banyaknya jenis atau varian produk yang ditawarkan kepada konsumen akan menjadikan konsumen memiliki banyak pilihan dan minat beli konsumen semakin tinggi untuk membeli suatu produk. Minat beli merupakan kecendrungan konsumen untuk membeli suatu merek atau mengambil tindakan yang berhubungan dengan pembelian yang diukur dengan tingkat kemungkinan konsumen melakukan pembelian (Assael 2001). Dengan adanya produk produk baru yang memiliki keunggulan dibandingkan produk lainnya akan meningkatkan kemungkinan konsumen untuk melakukan pembelian terhadap produk tersebut terlebih lagi produk tersebut dapat sesuai dengan apa yang diharapkan konsumen dan juga dapat memenuhi kebutuhan yang diinginkan oleh konsumen tersebut.

\section{B. LANDASAN TEORI \\ 1. Pengertian Harga}

Dalam arti sempit, harga (price) adalah jumlah yang ditagihkan atas suatu produk baik barang maupun jasa. Lebih luas lagi, harga adalah jumlah semua nilai yang diberikan oleh pelanggan untuk mendapatkan keuntungan dari memiliki atau menggunakan suatu produk baik barang maupun jasa (Kotler 2008). Peter dan Olson (2000) menyatakan bahwa persepsi harga berkaitan dengan bagaimana informasi harga dipahami seluruhnya oleh konsumen dan memberikan makna yang dalam bagi mereka. Pada saat konsumen melakukan evaluasi dan penelitian terhadap harga dari suatu produk sangat dipengaruhi oleh prilaku dari konsumen itu sendiri. Dengan demikian penilaian terhadap harga suatu produk dikatakan mahal, murah atau biasa saja dari setiap individu tidaklah harus sama karena tergantung dari persepsi individu yang dilatarbelakangi oleh lingkungan kehidupan dan kondisi individu.

Fandy Tjiptono (2008) menjelaskan harga memiliki dua peranan utama dalam pemasaran, yakni peranan alokasi, yaitu membantu para pembeli untuk memutuskan cara terbaik dalam memperoleh manfaat yang diharapkan sesuai dengan kemampuan daya belinya. Dengan demikian, adanya harga dapat membantu pembeli untuk memutuskan cara mengalokasikan daya belinya pada berbagai jenis barang atau jasa. Pembeli membandingkan harga dari berbagai alternatif yang tersedia, kemudian memutuskan alokasi dana yang dikehendaki. Kedua adalah peranan informasi, yaitu mendidik konsumen mengenai faktor produk yang dijual, misalnya kualitas. Hal ini terutama bermanfaat dalam situasi dimana pembeli mengalami kesulitan untuk menilai faktor produk atau manfaatnya secara objektif. 
Persepsi yang sering berlaku adalah bahwa harga yang mahal mencerminkan kualitas yang tinggi. Sedangkan Tjiptono (2008) menyatakan indikator harga yang dapat digunakan dalam pemasaran adalah perbandingan harga dengan produk lain, yaitu bagaimana perbandingan harga produk dengan produk pesaingnya, kesesuaian harga dengan kualitas produk, yaitu apakah harga yang di tawarkan sudah sesuai dengan kualitas produk yang didapatkan, serta keterjangkauan harga, yaitu adalah keterjangkauan harga yang ditawarkan produsen kepada konsumen. Persepsi harga diukur dengan indikator kesesuaian harga dengan kualitas produk, kesesuaian harga dengan manfaat, kemampuan harga untuk bersaing.

Produk private label sudah menjadi topik menarik penelitian dengan pendapat yang beragam. Kakkoset. al. (2015) menyatakan sejumlah faktor yang penting dalam pembentukan minat beli pada produk private label di ritel modern, seperti kesadaran akan adanya merek tersebut (brand awareness), faktor sosial, serta resiko yang dipersepsikan untuk barangbarang tertentu. Sedangkan Bramasto dan Indriani (2017) selain menyatakan bahwa persepsi akan resiko kualitas pada produk private label, penelitian mereka juga menyatakan bahwa pria pada umumnya bersedia untuk mengambil resiko terhadap produk private label dibandingkan konsumen wanita.

\section{Pengertian Citra Merek}

Kotler dan Keller (2008) mendefinisikan merek sebagai nama, istilah, tanda, simbol, atau rancangan, atau kombinasinya, yang dimaksudkan untuk mengidentifikasikan barang atau jasa dari salah satu penjual atau kelompok penjual dan mendiferensiasikan dari barang atau jasa pesaing. Sedangkan Ginting (2011) mendefinisikan merek adalah suatu nama, istilah, tanda, simbol, desain atau kombinasi daripadanya untuk menandai produk atau jasa dari satu penjual atau kelompok penjual dan untuk membedakannya dari pesaing. Akbar (2012:17) menyatakan bahwa merek memiliki berbagai macam fungsi, seperti sebagai identitas perusahaan yang membedakannya dengan produk pesaing, sebagai alat promosi yang menonjolkan daya tarik produk, untuk membina citra, yaitu dengan memberikan keyakinan, jaminan kualitas, serta citra prestise tertentu kepada konsumen, dan untuk mengendalikan dan mendominasi pasar. Artinya, dengan membangun merek yang terkenal, bercitra baik, dan dilindungi hak eksklusif berdasarkan hak cipta/paten, maka perusahaan dapat meraih dan mempertahankan loyalitas konsumen. Indikator dari brand image atau citra merek Punjabi (2010) meliputi kesan profesional dari produk dan merek, kesan modern dari produk atau merek, kemampuan merek untuk melayani semua segmen, serta perhatian produk dan merek kepada konsumen.

\section{Pengertian Kualitas Produk}

Menurut Kotler dan Armstrong (2008) kualitas produk adalah kemampuan sebuah produk dalam memperagakan fungsinya; hal ini termasuk keseluruhan durabilitas, reliabilitas, ketepatan, kemudahan pengoperasian, dan reparasi produk, juga atribut produk lainnya. Sedangkan menurut Yoestini (2012) kualitas adalah keunggulan yang dimiliki oleh produk tersebut.Kualitas dalam pandangan konsumen adalah hal yang mempunyai ruang lingkup tersendiri yang berbeda dengan kualitas dalam pandangan produsen saat mengeluarkan suatu produk yang biasa dikenal kualitas sebenarnya.

\section{Pengertian Minat Beli}

Menurut Kotler dan Keller (2009) minat beli adalah suatu keadaan dalam diri seseorang pada dimensi kemungkinan subyektif yang meliputi hubungan antar orang itu sendiri dengan beberapa tindakan. Sedangkan faktor-faktor yang mempengaruhi minat beli konsumen menurut Swastha dan Irawan (2001) adalah bila seseorang merasa senang dan puas dalam membeli barang atau jasa maka hal itu akan memperkuat minat membeli, ketidakpuasan biasanya menghilangkan minat mengulang pembeliannya. Sedangkan Mustapa et. al. (2018) mendefinisikan Minat Beli sebagai perilaku konsumen untuk merespon positif pada kualitas pelayanan suatu merek dan berminat melakukan konsumsi kembali produk atau merek 
tersebut. Menurut Kotler et al. (1999) terdapat dua faktor yang mempengaruhi minat beli sesorang dalam proses pengambilan keputusan pembelian, yaitu situasi tidak terduga (Unexpected situation) dan sikap terhadap orang lain (Respect to Others). Pengukuran variabel minat beli menurut Punjabi (2010) lewat indikator tertarik untuk mencari informasi produk, ingin mengetahui produk dan merek, mempertimbangkan untuk membeli produk atau merek, tertarik untuk mencoba produk atau merek, serta ingin memiliki produk atau merek. Penelitian Lai dan Govindan (2017) mengemukakan sejumlah faktor yang berpengaruh pada minat beli di ritel modern, seperti faktor kualitas produk, harga, citra merek.

\section{Kerangka Berpikir}

1. Pengaruh persepsi harga terhadap minat beli konsumen

Harga sebuah produk tentunya sangat berpengaruh terhadap minat beli konsumen. Konsumen akan melihat dan membandingkan harga sebuah produk sejenis dan melihat apakah harga yang mereka keluarkan akan memberikan kepuasan yang sama dengan nilai dari sebuah produk tersebut. Penilaian terhadap harga sangat dipengaruhi oleh persepsi dari konsumen itu sendiri hingga pada akhirnya suatu produk dapat dikatakan memiliki harga yang mahal ataupun murah.

2. Pengaruh citra merek terhadap minat beli konsumen

Brand image atau citra merek merupakan seperangkat keyakinan, ide, dan kesan terhadap suatu merek. Oleh karena itu keputusan yang diambil konsumen terhadap suatu merek sangat dipengaruhi oleh citra merek dari merek itu sendiri. Suatu merek harus memiliki keunggulan dibandingkan dengan merek yang lain agar merek tersebut dapat memiliki citra merek yang baik pula dibenak konsumen sehingga dapat menarik minat beli konsumen terhadap merek tersebut. Dengan citra merek yang positif maka posisi merek tersebut dapat menjadi merek yang kuat dibandingkan pesaingnya.Citra merek berpengaruh terhadap minat beli konsumen apalagi jika seorang konsumen loyal terhadap suatu merek, maka dia akan menggunakan merek itu secara berkelanjutan.

3. Pengaruh kualitas produk terhadap minat beli konsumen

Kualitas merupakan persepsi atau anggapan dari konsumen terhadap keseluruhan kualitas atau keunggulan suatu produk baik berupa barang atau jasa layanan berkaitan dengan kesesuaian dengan apa yang diharapkan dan dibutuhkan konsumen. Persepsi kualitas mencerminkan anggapan ataupun perasaan konsumen secara menyeluruh mengenai suatu merek dari produk yang digunakan. Dengan adanya persepsi konsumen yang positif terhadap kualitas suatu produk maka produk tersebut akan tampak berkualitas tinggi di mata konsumen di bandingkan dengan produk lain sejenis. Para pelaku bisnis lebih memperhatikan kualitas dari suatu produk dengan menggunakan berbagai konsep agar produk yang dihasilkan memiliki kualitas yang tinggi pula dan dengan begitu persepsi kualitas terhadap produk tersebut akan tinggi dan akan berpengaruh terhadap minat beli konsumen terhadap produk tersebut.

4. Pengaruh persepsi harga, citra merek, dan kualitas produk terhadap minat beli konsumen Harga yang sesuai dengan kualitas, mampu bersaing dengan harga produk merek lainnya, mempunyai citra merek yang positif yang telah dikenal serta dipercaya di mata konsumen tentu akan menciptakan kesan tersendiri di benak konsumen ketika ingin berbelanja,dan kualitas produk private label Indomaret yang sesuai dengan kebutuhan dan keinginan konsumen sehingga bisa memberikan kepuasan konsumen tentunya akan menarik perhatian konsumen dan menimbulkan minat beli dan atau akan membuat konsumen akan membeli ulang produk private label yang akan menciptakan sifat loyalitas konsumen terhadap produk private label itu sendiri. 
Berdasarkan kerangka berpikir diatas, maka paradigma adalah penelitian sebagai berikut:

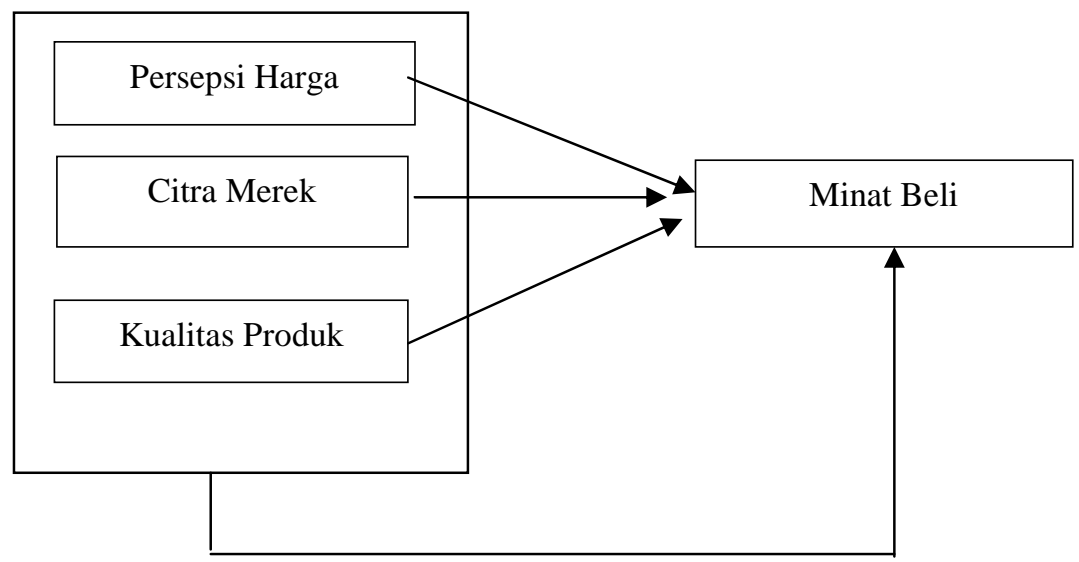

\section{Gambar 1: Model Penelitian}

Berdasarkan kerangka berpikir sebelumnya, maka hipotesis yang diajukan dalam penelitian ini adalah :

$\mathbf{H}_{\mathbf{1}}$ : Persepsi harga secara parsial berpengaruh positif terhadap minat beli

$\mathbf{H}_{2}$ : Citra merek secara parsial berpengaruh positif terhadap minat beli

$\mathbf{H}_{3}$ : Kualitas produk secara parsial berpengaruh positif terhadap minat beli

H4 : Persepsi harga, citra merk dan kualitas produk secara bersama-sama berpengaruh positif terhadap minat beli

\section{METODE PENELITIAN}

Penelitian ini berjenis kuantitatif dengan pendekatan survey. Data yang digunakan adalah data primer dengan alat bantu berupa instrument kuesioner atau angket. Berdasarkan tingkat eksplanasinya, penelitian ini tergolong sebagai penelitian asosiatif atau hubungan, yaitu penelitian untuk mengetahui hubungan sebab akibat. Hubungan atau pengaruh variabel bebas (X) terhadap variabel terikat (Y) (Sugiyono 2010).

Lokasi penelitian dilakukan di Yogyakarta. Penelitian dilakukan pada bulan November 2017 pada konsumen yang pernah berbelanja di beberapa gerai Indomaret di Yogyakarta.

Populasi pada penelitian ini adalah seluruh konsumen yang pernah melakukan pembelian dan mengetahui produk private label Indomaret di beberapa gerai Indomaret di Yogyakarta. Sedangkan sampel yang diambil dalam penelitian ini sebanyak 100 responden dengan teknik pengambilan sampel yaitu purposive sampling.

Untuk membantu peneliti mendapatkan jawaban dari responden, digunakan alat bantu kuisioner yang berisi pertanyaan tertutup dengan serangkaian alternatif pilihan jawaban yang terdapat di dalam kuesioner. Alternatif jawaban yang terdapat dalam kuesioner merupakan pengembangan dari setiap item dalam variabel penelitian. Kuesioner dibagi menjadi dua bagian. Bagian pertama berisi mengenai informasi data reponden meliputi jenis kelamin, usia, tingkat pendidikan terakhir, pengeluaran per bulan, pekerjaan, dan frekuensi berkunjung ke Indomaret dalam tiga bulan terakhir. Bagian kedua berisi mengenai pertanyaan-pertanyaan yang digunakan untuk mengukur variabel-variabel dalam penelitian. Informasi pribadi responden diperlukan untuk membantu menjelaskan karakteristik sampel dalam penelitian. Dalam penelitian ini indikator-indikator diukur dengan menggunakan skala Likert yang mempunyai lima tingkat preferensi yang masing-masing memiliki skor antara 1 (sangat tidak setuju) sampai 5 (sangat setuju). 
Sebelum kuesioner digunakan dalam penelitian, dilakukan pengujian Uji Validitas dan reliabilitas. Suatu indikator dikatakan valid jika benar-benar mengukur konstruk, sedangkan reliabel jika jawaban seseorang terhadap pertanyaan adalah konsisten atau stabil dari waktu ke waktu (Ghozali 2011).

Selanjutnya, dari data valid yang masuk, dilakukan teknik analisis data. Analisis data dibagi menjadi analisis deskriptif dan analisis regresi berganda. Analisis Deskriptif digunakan untuk memberikan gambaran responden, apakah dengan karakteristik responden yang berbeda-beda mempunyai penilaian yang sama ataukah tidak. Dalam penelitian ini yang dijadikan sebagai karakteristik responden meliputi: jenis kelamin, usia, pendidikan, pengeluaran, pekerjaan dan frekuensi berkunjung ke Indomaret selama tiga bulan terakhir. Sedangkan Analisis regresi berganda dalam penelitian ini bertujuan untuk mengetahui besarnya pengaruh variabel independen (persepsi harga, citra merek dan kualitas produk) terhadap variabel dependen (minat beli) dengan menggunakan rumus:

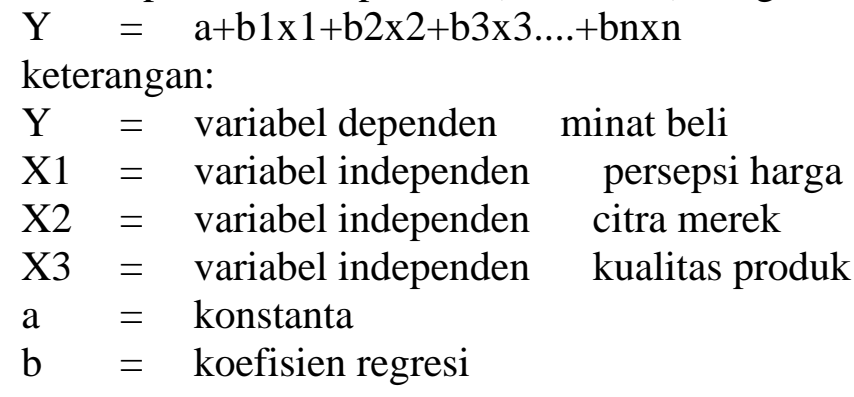

\section{HASIL PENELITIAN DAN PEMBAHASAN}

\section{Analisa Deskriptif}

Hasil analisis deskriptif untuk karakteristik responden yang meliputi jenis kelamin, usia, pendidikan, pengeluaran, pekerjaan dan frekuensi berkunjung ke Indomaret selama 3 bulan terakhir. Dari data primer yang masuk, diketahui bahwa mayoritas responden adalah perempuan yaitu sebanyak 66 orang $(66,0 \%)$, usia mayoritas 20-30 tahun yaitu sebanyak 69 orang $(69,0 \%)$, pendidikan terakhir mayoritas adalah lulusan SMA/SMK yaitu sebanyak 70 orang $(70,0 \%)$, pengeluaran per bulan mayoritas antara Rp 1.000.000,00 - Rp. 3.000.000,00 yaitu sebanyak 90 orang $(90,0 \%)$, pekerjaan mayoritas adalah pelajar/mahasiswa yaitu sebanyak 89 orang $(89,0 \%)$, dan yang terakhir adalah frekuensi kunjungan dalam 3 bulan terakhir lebih dominan pada $<5$ kali yaitu sebanyak 41 orang $(41,0 \%)$.

\section{Analisis Regresi Berganda}

Dari hasil Koefisien Determinasi (Adjusted $R^{2}$ )yang berfungsi untuk mengukur besarnya pengaruh variabel bebas terhadap variabel terikat, diperoleh nilai sebesar 0,444 . Hal ini menunjukkan bahwa minat beli konsumen terhadap produk private label Indomaret di Yogyakarta dipengaruhi oleh persepsi harga, citra merek dan kualitas produk sebesar 44,4\%, sedangkan sisanya 55,6\% dipengaruhi oleh faktor lain yang tidak termasuk dalam penelitian ini (seperti daya beli, selera konsumen dan lainnya).

Selanjutnya, dari hasil analisis regresi berganda menunjukkan besaran dan arah regresi sebagai berikut:

\begin{tabular}{cc}
\multicolumn{2}{c}{ Tabel 1: Hasil Regresi Linear Berganda } \\
\cline { 2 - 2 } Model & Unstandardized Coefficients \\
\hline Constant & $-2,779$ \\
Persepsi Harga & 0,493 \\
Citra Merek & 0,068 \\
Kualitas Produk & 0,377 \\
\hline
\end{tabular}


Dari tabel di atas tampak bahwa semua koefisien variabel independen adalah positif, yang menunjukkan makin besar nilai variabel independen, amakin besar pula nilai variabel dependen.

\section{Uji Hipotesis}

Selanjutnya, untuk menguji hipotesis yang diajukan, dilakukan Uji-t dan Uji-F. Uji t digunakan untuk mengetahui pengaruh parsial dari masing-masing variabel independen terahdap variabel dependen. Dari hasil pengolahan data primer, hasil dari uji-t adalah:

Tabel 2: Hasil Uji t

\begin{tabular}{lcc}
\hline \multicolumn{1}{c}{ Model } & $\mathrm{t}$ & Sig. \\
\hline Constant & -1.191 & 0.238 \\
Persepsi Harga & 3.661 & 0.000 \\
Citra Merek & 0.554 & 0.581 \\
Kualitas Produk & 5.151 & 0.000 \\
\hline
\end{tabular}

Sumber: Data Primer 2018

Dengan melihat angka signifikansi dengan ketentuan jika angka tersebut di bawah 0,05 maka Hipotesis ditolak, didapatkan bahwa untuk variabel Persepsi harga (X1), secara parsial variabel tersebut berpengaruh signifikan terhadap minat beli konsumen pada produk private label Indomaret di Yogyakarta (Y); hal ini terlihat dari angka signifikansi yang adalah 0,000. Untuk variabel Citra Merek, secara parsial variabel tersebut tidak berpengaruh signifikan terhadap minat beli konsumen pada produk private label Indomaret di Yogyakarta (Y); hal ini terlihat dari angka signifikansi yang adalah 0,581. Sedangkan untuk variabel Kualitas Produk, variabel tersebut berpengaruh signifikan terhadap minat beli konsumen pada produk private label Indomaret di Yogyakarta (Y); hal ini terlihat dari angka signifikansi yang adalah 0,000.

Selanjutnya, untuk mengetahui pengaruh semua variabel (persepsi harga, citra merek dan kualitas produk) terhadap minat beli produk private label Indomaret di Yogyakarta. Dari Uji F (Fisher) didapat hasil sebagai berikut:

\begin{tabular}{|l|l|l|l|l|c|}
\hline Model & $\begin{array}{l}\text { Sum of } \\
\text { Squares }\end{array}$ & df & Mean Square & F & Sig. \\
\hline Regression & 404.841 & 3 & 134.947 & 27,373 & $.000_{\bar{a}}$ \\
\hline Residual & 473.269 & 96 & 4.930 & & \\
\hline Total & 878.110 & 99 & & & \\
\hline
\end{tabular}
Sumber: Data Primer 2018

Dari hasil penelitian ini, hasil uji $\mathrm{F}$ diperoleh nilai $\mathrm{F}$ hitung sebesar 27,373 dengan signifikansi sebesar 0,000. Oleh karena nilai signifikansi lebih kecil dari $0,05(0,000<0,05)$, maka dapat disimpulkan bahwa hipotesis yang menyatakan "persepsi harga, citra merek dan kualitas produk secara simultan berpengaruh terhadap minat beli konsumen pada produk private label Indomaret di Yogyakarta" diterima.

Dari hasil penelitian tersebut diatas, didapat hasil yang positif antara persepsi harga terhadap minat beli produk private label Indomaret di Yogyakarta mendukung penelitian sebelumnya yang dilakukan oleh Luftiani (2016) tentang pengaruh Persepsi Kualitas, Citra Merek dan Persepsi Harga Terhadap Minat Pembelian pada Produk Merek Toko pada Konsumen Bio Organik di Supermarket SuperIndo Yogyakarta; juga mendukung hasil riset dari Siahaan (2011) bahwa persepsi harga berpengaruh positif dan signifikan terhadap minat beli produk private label. Hal ini juga sesuai dengan penelitian yang dilakukan oleh Kristinae, V. (2018) serta Istiyanto, B., \& Nugroho, L. (2017). Riset dari Kakkos et. al. (2015) juga menyatakan bahwa harga yang murah untuk private label (value for money) berpengaruh 
secara positif dan signifikan terhadap minat membeli produk di ritel modern. Namun hasil penelitian ini berbeda dengan penelitian Kusuma (2015) bahwa persepsi harga berpengaruh tidak signifikan terhadap minat beli produk private label pada Minat Pembelian Produk Merek Alfamart di Surabaya.

Untuk hasil bahwa citra merek berpengaruh terhadap minat beli produk private label Indomaret di Yogyakarta, hal ini berbeda dengan penelitian dari Luftiani (2016). Tidak berpengaruhnya variabel Citra merek mungkin disebabkan merek yang diteliti pada penelitian tersebut (Indomaret) dianggap kalah dengan produk private label Indomaret, selain faktor pemelian pada produk yang sudah menjadi loyalitas konsumen akan sulit dilakukan pengalihan merek (brand switching) oleh konsumen. Sedangkan untuk pengaruh kualitas produk terhadap minat beli produk private label Indomaret di Yogyakarta yang positif, mendukung penelitian yang dilakukan oleh Kusuma (2015) tentang pengaruh Harga, Kualitas dan Risiko yang Dipersepsikan Terhadap Minat Pembelian Produk Merek Alfamart di Surabaya. Penelitian Mustapa et. al. (2018) pada pembelian ulang suku cadang Toyota juga menunjukkan hubungan positif antara kualitas produk dengan minat untuk membeli ulang produk tersebut. Riset Rofiq dan Hufrom (2018) juga menyatakan hal serupa saat meneliti pengaruh kualitas produk di Powernoise kota Malang. Kualitas produk tentunya akan berhubungan dengan kepuasan konsumen terhadap produk yang mereka konsumsi. Sedangkan penelitian dari Bramasto dan Indriani (2017) menunjukkan kedua variabel, yakni persepsi harga dan pesepsi akan kualitas produk berpengaruh pada minat beli produk private label. Penelitian Lai dan Govindan (2017) mendukung hasil penelitian ini, bahwa citra merek, persepsi harga dan kualitas produk, semuanya berpengaruh pada pembelian produk private label.

Dari pembahasan di atas memang ada beberapa hasil penelitian yang tidak mendukung hipotesis yang ada, namun secara keseluruhan dapat dikatakan bahwa persepsi pada harga dan kualitas produk yang memang bagus ternyata berpengaruh secara positif dan signifikan pada keinginan membeli produk private label. Produk private label, walaupun ditandai dengan nama peritel, namun jika memang dibuat dengan kualitas yang bagus, disertai dengan pemberian harga yang tidak mahal, bahkan banyak yang lebih murah dibanding produk dengan merek terkenal, tetap akan dipandang positif oleh konsumen karena ada daya tarik dari merek peritel yang sudah terkenal, seperti Indomaret, Alfamart, dan lainnya. Sedangkan untuk citra merek, variabel tersebut tidak berpengaruh karena pembeli lebih mengenal merek peritel daripada merek private label.

\section{E. PENUTUP}

Dari hasil penelitian diatas, dapat disimpulkan bahwa variabel persepsi harga dan kualitas produk berpengaruh signifikan terhadap minat beli konsumen pada produk private label Indomaret di Yogyakarta, sedangkan citra merek tidak berpengaruh signifikan terhadap minat beli konsumen pada produk private label Indomaret di Yogyakarta. Tetapi secara keseluruhan persepsi harga, citra merek dan kualitas produk secara simultan berpengaruh signifikan terhadap minat beli konsumen pada produk private label Indomaret di Yogyakarta. Berangkat dari simpulan diatas, disarankan kepada perusahaan agar bisa mempertahankan tentang persepsi harga dan kualitas produk dan lebih meningkatkan tentang citra merek dengan melakukan strategi-strategi untuk lebih meningkatkan citra Indomaret di mata masyarakat umum supaya bisa bersaing dengan minimarket sejenis. 
Untuk penelitian selanjutnya dapat mengembangkan penelitian ini dengan menambah faktor-faktor lain yang dapat mempengaruhi pembelian produk private label, seperti kesadaran akan merek private label, persepsi resiko atas produk private label, dan lainnya.

\section{DAFTAR PUSTAKA}

Assael, H. (2001). Consumer behavior, sixth edition. New York: Thomson Learning.

Assauri, S. (1993). Manajemen produksi, edisi ketiga. Jakarta: Fakultas Ekonomi Universitas Indonesia.

Bramasto, A., \& Indriani, F. (2017). Analisis faktor-faktor yang mempengaruhi minat beli produk private label. Diponegoro Journal of Management 6 (4): 1-12.

Dharmmesta, B. S. and Irawan. (2001). Manajemen pemasaran modern, edisi kedua. Jakarta: Erlangga.

Ginting, N. F. H. (2011). Manajemen pemasaran. Bandung: CV Yrama Widya.

Hair, J. F., Black, W. C., \& Babin, B. J. (2010). Multivariate data analysis, seventh edition. New Jersey: Pearson Prentice Hall.

Istiyanto, B., \& Nugroho, L. (2017). Analisis Pengaruh Brand Image, Harga, Dan Kualitas Produk Terhadap Keputusan Pembelian Mobil (Studi Kasus Mobil LCGC di Surakarta). Eksis: Jurnal Riset Ekonomi dan Bisnis, 12(1 Apr).

Kakkos, N., Trivellas, P., \& Sdrolias, L. (2015). Identifying Drivers of Purchase Intention for Private Label Brands: Preliminary Evidence from Greek Consumers.Procedia - Social and Behavioral Sciences 175: 522 - 528.

Kotler, P., Bowen, J., \& Makens, J. (1999). Marketing for Hospitality and Tourism, second Edition. New Jersey: Prentice Hall Inc.

Kotler, P., \& Armstrong, G. (2006). Principles of marketing, eleven edition. New Jersey: Prentice Hall. Pearson Education, Inc. Upper Saddle River.

Kotler, P., dan G. Armstrong. (2008). Prinsip-prinsip pemasaran, edisi 12, jilid 1. Jakarta: Erlangga.

Kotler, P dan Keller, K. (2009). Manajemen pemasaran, Jakarta: Erlangga.

Kristinae, V. (2018). Pengaruh Produk, Harga dan Promosi Terhadap Minat Konsumen Untuk Melakukan Pembelian Kerajinan Tangan Rotan. Eksis: Jurnal Riset Ekonomi dan Bisnis, 13(1), 25-30.

Kusuma, A. F. (2015). Pengaruh Harga, kualitas, Dan Resiko Yang Dipersepsikan Terhadap Minat Pembelian Produk Merek Alfamart Di Surabaya. Working Paper: STIE Perbanas Surabaya.

Lai S. J. \& Govindan, S. (2017). Opportunities of private label brands at Malaysia. Journal of Global Business and Social Entrepreneurship 3 (7): 59-70.

Luftiani, E. I. (2016). Pengaruh Persepsi Kualitas, Citra Merek, dan Persepsi Harga Terhadap Minat Pembelian pada Produk Merek Toko (Studi Kasus pada Konsumen Bio Organik di Supermarket Superindo Yogyakarta). Working Paper: Universitas Negeri Yogyakarta.

Mustapa, A., Patricia, D. P., \& Leonardo, B.H. (2018). Pengaruh kualitas produk, harga produk, dan keragamaan produk sparepart toyota terhadap minat beli ulang konsumen dengan kepuasaan pelanggan sebagai variabel. Journal of Management Universitas pandanaran 4 (4): 1-17.

Nur Aini, Q., Suharyono, Hidayat, K. (2016). Pengaruh atmosfer toko dan promosi penjualan terhadap shopping emotion dan pembelian tidak terencana. Jurnal Administrasi Bisnis 37 (1): 164-170.

Peter, J. P. \& Olson, J. C. (2000). Consumer behavior: Perilaku Konsumen dan Strategi Pemasaran jilid 1, edisi keempat. Jakarta: Erlangga. 
Punjabi, B. (2010). Pengaruh Citra Merek terhadap Minat Beli melalui Sikap terhadap Merek (Studi Kasus pada merek pasta gigi ciptadent di Semarang). Working Paper: Universitas Diponegoro.

Rofiq, A. \& Hufrom, M. (2018). Pengaruh kualitas produk, harga dan lokasi terhadap keputusan pembelian di powernoise store. Jurnal Ilmiah Riset Manajemen Vol 7 (2): 152-167.

Siahaan, S. M. (2011). Pengaruh Persepsi Nilai Konsumen Terhadap Perilaku Pembelian Private Label Carrefour Plaza Medan Fair. Working Paper: Universitas Sumatra Utara.

Soliha, E. (2008). Analisis industri ritel di indonesia. Jurnal Bisnis dan Ekonomi 15 (2): 128 142.

Sugiyono. (2010). Metode penelitian kuantitatif kualitatif \& rnd. Bandung: Alfabeta

Tjiptono, F. (2008). Strategi pemasaran, edisi tiga. Yogyakarta: ANDI.

Yoestini, I. N. S. (2012). Analisis pengaruh citra merek, kualitas produk, dan harga terhadap minat beli produk oriflame. Diponegoro Journal of Management 1 (1): 1-17. 